\title{
Protection of Turbidity on Reefs along the Southeast Coast of the Kalimantan during the 2015 El Niño
}

\author{
SUHAILI ASMAWI ${ }^{1,2}$, MUHAMMAD AHSIN RIFA'I ${ }^{2}$, IDIANNOR MAHYUDIN ${ }^{2}$, AND \\ MUHAMMAD RUSLAN ${ }^{3}$
}

\author{
${ }^{1}$ Doctoral Study Program of Agricultural Science, Postgraduate Program, Lambung Mangkurat \\ University, J1. A. Yani KM. 36 Banjarbaru 70714, Indonesia \\ ${ }^{2}$ Faculty of Fisheries and Marine, Lambung Mangkurat University, Jl. A. Yani KM 36 Banjarbaru \\ 70714, Indonesia \\ ${ }^{3}$ Faculty of Forestry, Lambung Mangkurat University, Jl. A. Yani KM 36 Banjarbaru 70714, \\ Indonesia
}

\begin{abstract}
Bleaching is a major threat to coral reef ecosystems around the world. This study aimed to determine the effect of turbidity on the severity of coral bleaching and mortality in Kalimantan due to thermal stress and high solar irradiation caused by the $2015 \mathrm{El}$ Niño. Coral colonies in eighteen permanent bleaching belt transects $(50 \mathrm{~m} \mathrm{x} 1 \mathrm{~m})$ in six sites were observed from June to November 2015, coinciding with the 2015 El Niño. Water depth, sea surface temperature (SST), salinity, turbidity, sedimentation and total suspended solid (TSS) were measured on the same transect. Three permanent bleaching belt transects were applied randomly on each reef. Species and bleaching status of each coral colony (diameter $>5 \mathrm{~cm}$ ) in belt transects were identified. The bleaching status was measured Coral species were identified in the field. Results showed that the $2015 \mathrm{El}$ Niño was a major disaster for reefs on the southeast coast of the Kalimantan. Of total colonies $(\mathrm{N}=12,954), 45.4 \%$ of colonies were bleached and $14.7 \%$ of colonies were died during the period of July to November 2015. Turbidity, TSS, and sedimentation were negatively correlated with the bleaching mortality index (BMI). Coral bleaching in clear and deep waters occurred earlier and increased rapidly compared to that in turbid waters. However, the severity of coral bleaching in turbid zone increased dramatically when the turbidity dropped to $<3$ NTU. Turbidity $>5$ NTU could provide shade, in which the proportion of dead corals was only 3.5\%. The severity of coral bleaching in turbid zone is not solely due to thermal stress and solar irradiation; it may also be influenced by a history of exposure to high turbidity and low salinity.
\end{abstract}

Keyword: El Niño 2015, coral protection, coral bleaching, turbidity, shading

\section{INTRODUCTION}

Coral reefs are one of the most diverse and economically valuable marine ecosystems in the world (Bellwood et al., 2003; Cesar et al., 2003), but they are the most threatened by environmental stress (Halpern et al., 2007; Burke, 2011). Correspondence Author: Suhaili Asmawi. Faculty of Fisheries and Marine, Lambung Mangkurat University, Jl. A. Yani KM 36 Banjarbaru 70714, Indonesia. Email: ataksuhai@gmail.com.

Journal of Wetlands Environmental Management Vol 8, No 2 (2020) 45 - 62 http://dx.doi.org/10.20527/10.20527/jwem.v8i1.216
Bleaching is a response to environmental stresses and is a major threat to coral reef ecosystems around the world (Glynn, 1993; Wilkinson et al. 1999; Cesar, 2000; Eakin et al., 2009). High turbidity, sedimentation, and low salinity may trigger coral bleaching (Philipp and Fabricius, 2003); but major cause of bleaching is thermal stress (Brown 1997; Hoegh-Guldberg, 1999; Baird et al., 2009). Previous studies showed that the frequency and intensity of coral bleaching in 
the world has increased as the sea surface temperature (SST) increased in the last decade (Donner, 2005; Hoegh-Guldberg et al., 2007; Baker et al., 2008). The El NiñoSouthern Oscillation in 1997-1998 was suggested to cause the highest increases in the SST during this century (Kerr, 1999), lead to world mass bleaching coral reefs in the world, including to those occurring in the East Kalimantan (Wilkinson, 1999).

The level of coral bleaching is not only influenced by the intensity and duration of the increase in the SST (Fitt et al., 2001; Lasser 2011), but it also related the composition of coral communities (Marshall \& Baird 2000, Loya et al. 2001, McClanahan 2004; van Woesik, 2011) and exposure to irradiance (Coles and Jokiel, 1978; HoeghGuldberg, 2000; Dunne and Brown 2001; Lesser and Farrell, 2004). The irradiance of the water is influenced by turbidity, the optical character of the suspension which causes light to be scattered and absorbed by the water column (Davies-Colley and Smith, 2001). Turbidity in coastal waters is associated with terrestrial runoff and resuspended sediments by wind, currents and tides (Storlazzi et al., 2004, Piniak and Storlazzi, 2008). Reduction of the light for photosynthesis causes physiological stress or even coral death (Fortes, 2000; Phillip and Fabricius, 2003; Piniak and Brown, 2008), encouraging changes in the percentage of coral cover and coral community structure (Cooper and Fabricius, 2007). On the other hand, high turbidity may also function as a shade for corals against solar radiation (Rogers, 1990; Goreau et al., 2000; Obura, 2001; Negri, et al., 2005) and may reduce harmful effect of irradiance in shallow water (Bracchini et al. 2004).
The intensity of irradiance is strongly influenced by turbidity and sedimentation. Turbidity and decrease of light intensity vary spatially and temporally depending on the proximity of the terrestrial runoff source (Fabricius 2005) and changes in local weather conditions (Orpin et al. 2004, Wolanski et al., 2005). Cooper (2008) reported that turbidity of $\geq 5$ NTU lead to 94\% reduction the intensity of seabed irradiance. Turbidity and light attenuation may reduce coral growth rates, survival of colonies and recruitment of new corals, and coral biodiversity (Rogers, 1979; Babcock and Smith, 2002; De'ath and Fabricius, 2010) and increase bioerosion (LeGrand and Fabricius, 2011). However, decreases in light irradiation due to increasing suspended particles (Tedetti and Sempere, 2006) are reported to reduce the bleaching (Goreau et al., 2000; Otis et al., 2004).

High rainfall (>3,000 $\left.\mathrm{mm} \mathrm{year}^{-1}\right)$ and massive land conversion into mining and plantation areas causes an increase in the potential for flooding in the Kalimantan. Although terrestrial runoff may be reduced, nearshore waters tend to be always turbid because the sediments experience a cycle of sedimentation and resuspension (Fabricius, 2005). Furthermore, increases in the turbidity due to sediment resuspension depend on the changes in local weather conditions (Orpin et al. 2004, Wolanski et al., 2005). Most of the coral reefs on the southeast coast of Kalimantan are situated in coastal waters; therefore, they exposed annually to flood plumes from the rivers which flow into these waters. In addition, the coral reefs in these areas are generally located at a depth of $\leq 10$ meters. Based on the combination of the effect of flood plume and the potential of sediment resuspension, the coral reefs in the 
southeast coast of Kalimantan might be segmented in several micro-habitat; which the differences in habitat are very likely to affect coral susceptibility to the thermal stress (Wagner et al., 2010).

In a recent study in Florida and Palau, the lowest coral bleaching was found in the warm and turbid nearshore corals (Wagner et al., 2010; van Woesik et al., 2012), which turbidity function as a shade to reduce high irradiation pressure on the reef during periods of thermal anomaly. The $2015 \mathrm{El}$ Niño provides an opportunity to enhance our understanding on environmental factors affecting coral resilience against thermal stress in turbid waters in the southeast coast of Kalimantan. Therefore, our specific objective is to determine: (1) the effect of turbidity on the severity of coral bleaching during the 2015 El Niño, and (2) relationship between coral bleaching patterns and environmental factors.

\section{RESEARCH METHODS}

\section{Study areas}

Assessment of the bleaching and mortality of coral colonies, and measurement of environmental parameters were carried out on Ibu (346'26.25"S, 115³6'3.67"E), Anak Kima ( $\left.3^{\circ} 47^{\prime} 9.25^{\prime \prime S}, 115^{\circ} 36^{\prime} 43.73^{\prime \prime E}\right)$, Kima (347'44.24"S, 115 36'37.44"E), Bajangan Atak (346'52.50"S, 115 41'34.64"E), Batu Anjir (3॰48'38.41"S, $\left.115^{\circ} 36^{\prime} 58.65^{\prime \prime E}\right)$ and Bajangan reefs $\quad\left(3^{\circ} 49^{\prime} 54.22 " \mathrm{~S}\right.$, $\left.115^{\circ} 37^{\prime} 9.74^{\prime \prime E}\right)$ in the Angsana sub-district, South Kalimantan, Indonesia (Figure 1).

The Ibu, the Anak Kima and the Kima Reefs are affected by the flood plume from the Angsana River, while the Bajangan Atak Reef is influenced by the sediment from the

Journal of Wetlands Environmental Management

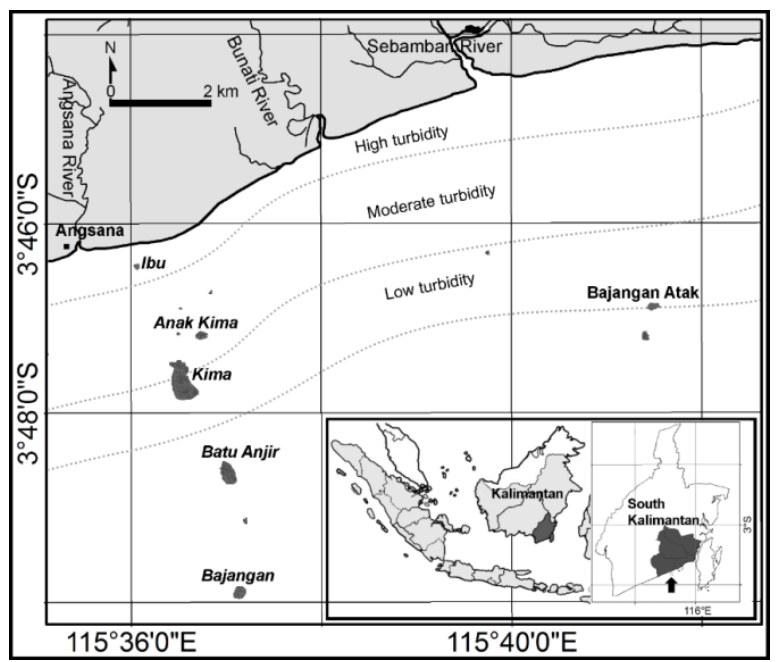

Figure 1. Location of the Ibu, Anak Kima, Kima, Bajangan Atak, Batu Anjir and Bajangan Reefs.

Bunati and Sebamban Rivers. The Ibu Rreef (0.21 nautical mile (NM) from coastline) is exposed to turbidity for 6 - 8 months annually, the Anak Kima Rreef (1.24 NM from coastline) is exposed to turbidity for 23 months annually were representative of coral reef in high and moderate turbidity areas, respectively. In the periods of high run off, around $40 \%$ of the Kima Reef (1.4 NM from coastline) and around $60 \%$ of the Bajangan Atak Reef (2.65 NM from coastline) are exposed to flood plume. Both experienced high turbidity for 1-2 months annually, and were designated as representative of low turbidity reefs. Clear and deeper water reefs represented by the Batu Anjir Reef (2.75 NM from coastline) is exposed to turbidity around 1-2 weeks annually while the Bajangan Reef (4.21 NM from coastline) was not affected by terrestrial runoff $^{1}$.

\footnotetext{
${ }^{1}$ The reach of flood plume is the result of observation by the author and information of local fishermen (unpublish data).
} 


\section{Field observation and sampling}

Three permanent bleaching belt transects (PBBT), 50 x 1 m (English et al., 1997), were applied randomly on each reef. Species and bleaching status of each coral colony (diameter $>5 \mathrm{~cm}$ ) in belt transects were identified. The bleaching status was measured as follows: $\left(\mathrm{c}_{1}\right)$ healthy $=$ no bleaching; $\left(\mathrm{c}_{2}\right)$ moderately bleached $=$ colony pale or less than $50 \%$ of surface area bleached; $\left(c_{3}\right)$, severe $=$ colony greater than $50 \%$ bleached; and $\left(\mathrm{c}_{4}\right)$ recently dead (Guest, 2012). Coral species were identified in the field based on Allen (1994), Veron (2000) and Kelley (2009). To ensure the identity of the reef, each type of coral was photographed, and then compared with the identification books. Environmental factors including sea surface temperature (SST), salinity, turbidity and total suspended solid (TSS) were measured in the field on monthly basis from June to November 2015 on each transect. SST was measured with $\mathrm{HACH}$ Pocket Pro + Multi 2 Tester, turbidity was measured as a nephelometric turbidity unit (NTU) using the HACH 2100Q portable turbidimeter, while TSS was measured by the photometric method using the $\mathrm{HACH}$ DR1900 portable spectrophotometer.

Three PVC sediment traps with a diameter of 2 inches and a length of 24 inches (ratio 1:12, Storlazzi et al., 2011) were installed in the middle of each PBBT. The sediment traps were moored on a stick that stands upright on the bottom of the water and were collected at each sampling time. After pouring seawater, the sediment was carefully moved into the polycarbonate sample bottle, and the sediment traps were reinstalled. The salt in the samples was removed by adding distilled water, and then the samples were taken to the laboratory for calculation of the sedimentation rate. Sediment samples were dried at $60{ }^{\circ} \mathrm{C}$ for 3 days before determining their dry weights.

\section{Data analysis}

The bleaching and mortality index (BMI) was calculated using the formula: $\mathrm{BMI}=$ $\left(0 c_{1}+1 c_{2}+2 c_{3}+3 c_{4}\right) / 3$ (McClanahan et al. 2004). All data were analyzed by software $R$ Software Version 3.2.3 (R Core Team, 2015). The relationship between BMI and environmental factors was graphically explained using the Multiple Frame Line Graph reinforced by Non-Metric MultiDimensional Scaling (NMDS) analysis (Vegan Package of R). Analysis of NMDS was conducted Bray-Curtis Distance, and data was standardized with Wisconsin double standardization. To test the variation of BMI in a micro-spatial (reefs) and temporal (months), factorial variant analysis was carried out followed by Multiple Comparisons of Means: Tukey Contrasts.

\section{RESULTS}

\section{Environmental factors}

Sea surface temperature (SST) and salinity in all sites increased from June to November 2015, while water depth, turbidity, TSS and sedimentation decreased in the same period. The lowest salinity was found on the Ibu Reef and the salinity increased for sites farther from shoreline. On the other hand, decreases in turbidity, TSS and sedimentation were observed for sites farther from shoreline (Table 1).

During the study period, the SST and salinity of all sites increased by $1.5 \pm 0.02{ }^{\circ} \mathrm{C}$

Journal of Wetlands Environmental Management 
Table 1. Valueas of environmental factors on coral reefs in different sites as observed monthly basis

\begin{tabular}{|c|c|c|c|c|c|c|c|}
\hline \multirow{2}{*}{ Parameters } & \multirow{2}{*}{ Month } & \multicolumn{6}{|c|}{ Reefs/Sites } \\
\hline & & Ibu & Anak Kima & Kima & Bajangan Atak & Batu Anjir & Bajangan \\
\hline \multirow[t]{7}{*}{ Water depth (m) } & June & $4.2 \pm 0$ & $5.8 \pm 0.26$ & $4.3 \pm 0.07$ & $5.1 \pm 0.1$ & $7.2 \pm 0.78$ & $9 \pm 0.21$ \\
\hline & July & $4.1 \pm 0.06$ & $5.7 \pm 0.32$ & $4.2 \pm 0.04$ & $5 \pm 0.15$ & $7.1 \pm 0.75$ & $8.9 \pm 0.29$ \\
\hline & August & $3.9 \pm 0$ & $5.5 \pm 0.32$ & $4 \pm 0.04$ & $4.8 \pm 0.06$ & $6.8 \pm 0.76$ & $8.7 \pm 0.26$ \\
\hline & September & $3.4 \pm 0.1$ & $4.9 \pm 0.32$ & $3.5 \pm 0.02$ & $4.3 \pm 0.06$ & $6.3 \pm 0.81$ & $8.2 \pm 0.32$ \\
\hline & October & $3 \pm 0.1$ & $4.4 \pm 0.32$ & $3.3 \pm 0.11$ & $4.1 \pm 0.1$ & $6.2 \pm 0.75$ & $8.1 \pm 0.26$ \\
\hline & November & $2.9 \pm 0.06$ & $4.1 \pm 0.32$ & $3.1 \pm 0.13$ & $3.9 \pm 0.12$ & $6 \pm 0.71$ & $7.9 \pm 0.29$ \\
\hline & Average & $3.6 \pm 0.04$ & $5.1 \pm 0.31$ & $3.7 \pm 0.06$ & $4.5 \pm 0.09$ & $6.6 \pm 0.76$ & $8.5 \pm 0.27$ \\
\hline \multirow[t]{7}{*}{$\operatorname{SST}\left({ }^{\circ} \mathrm{C}\right)$} & June & $28.5 \pm 0$ & $28.4 \pm 0.03$ & $28.4 \pm 0.06$ & $28.4 \pm 0.06$ & $28.4 \pm 0$ & $28.3 \pm 0.06$ \\
\hline & July & $28.6 \pm 0.33$ & $28.6 \pm 0.15$ & $28.6 \pm 0.12$ & $28.5 \pm 0.26$ & $28.5 \pm 0.1$ & $28.5 \pm 0.12$ \\
\hline & August & $28.8 \pm 0.1$ & $28.8 \pm 0.06$ & $28.8 \pm 0.1$ & $28.7 \pm 0.21$ & $28.6 \pm 0.06$ & $28.6 \pm 0.05$ \\
\hline & September & $29.5 \pm 0.12$ & $29.5 \pm 0.12$ & $29.4 \pm 0.15$ & $29.4 \pm 0.15$ & $29.4 \pm 0.09$ & $29.4 \pm 0.06$ \\
\hline & October & $29.7 \pm 0.06$ & $29.7 \pm 0.06$ & $29.7 \pm 0.17$ & $29.6 \pm 0.06$ & $29.6 \pm 0.13$ & $29.6 \pm 0.1$ \\
\hline & November & $30 \pm 0$ & $30 \pm 0.1$ & $30 \pm 0.15$ & $29.9 \pm 0.1$ & $29.9 \pm 0.06$ & $29.8 \pm 0.06$ \\
\hline & Average & $29.2 \pm 0.1$ & $29.2 \pm 0.07$ & $29.1 \pm 0.12$ & $29.1 \pm 0.11$ & $29 \pm 0.06$ & $29 \pm 0$ \\
\hline \multirow[t]{7}{*}{ Salinity (ppt) } & June & $17.5 \pm 0.15$ & $18.7 \pm 0.21$ & $21 \pm 0.15$ & $21.9 \pm 0$ & $27.1 \pm 0.15$ & $27.7 \pm 0.15$ \\
\hline & July & $21.1 \pm 0.1$ & $22.8 \pm 0.98$ & $23.7 \pm 0.32$ & $24.5 \pm 0.2$ & $27.8 \pm 0.15$ & $28.3 \pm 0.58$ \\
\hline & August & $25.6 \pm 0.21$ & $27.4 \pm 0.12$ & $27.5 \pm 0.26$ & $27.8 \pm 0.1$ & $28.9 \pm 0.2$ & $29.3 \pm 0.15$ \\
\hline & September & $31.6 \pm 0.15$ & $31.9 \pm 0.15$ & $31.9 \pm 0.1$ & $32 \pm 0.06$ & $32 \pm 0.06$ & $32 \pm 0.15$ \\
\hline & October & $32.1 \pm 0.15$ & $32.1 \pm 0.1$ & $32.2 \pm 0.06$ & $32.2 \pm 0.06$ & $32.2 \pm 0.1$ & $32.3 \pm 0.06$ \\
\hline & November & $32.4 \pm 0.1$ & $32.5 \pm 0.06$ & $32.5 \pm 0.1$ & $32.6 \pm 0.06$ & $32.6 \pm 0.06$ & $32.7 \pm 0.1$ \\
\hline & Average & $26.7 \pm 0.02$ & $27.6 \pm 0.24$ & $28.1 \pm 0.1$ & $28.5 \pm 0.05$ & $30.1 \pm 0.07$ & $30.4 \pm 0.17$ \\
\hline \multirow[t]{7}{*}{ Turbidity (NTU) } & June & $20.7 \pm 0.2$ & $15.1 \pm 0.49$ & $9 \pm 0.12$ & $9.4 \pm 0.06$ & $2.1 \pm 0.06$ & $1.4 \pm 0.06$ \\
\hline & July & $18.2 \pm 0.17$ & $11.6 \pm 0.32$ & $7.2 \pm 0.22$ & $7.9 \pm 0.09$ & $1.6 \pm 0.12$ & $1.1 \pm 0.12$ \\
\hline & August & $14.4 \pm 0.41$ & $8.1 \pm 0.47$ & $5.5 \pm 0.04$ & $6 \pm 0.08$ & $1 \pm 0.09$ & $0.7 \pm 0.07$ \\
\hline & September & $7.9 \pm 0.35$ & $3.7 \pm 0.09$ & $3 \pm 0.04$ & $3.1 \pm 0.04$ & $0.5 \pm 0.05$ & $0.3 \pm 0.04$ \\
\hline & October & $6.1 \pm 0.41$ & $2.1 \pm 0.02$ & $2.9 \pm 0.08$ & $3 \pm 0.02$ & $0.3 \pm 0.01$ & $0.04 \pm 0.01$ \\
\hline & November & $5.3 \pm 0.03$ & $1.6 \pm 0.05$ & $2.9 \pm 0.08$ & $2.9 \pm 0.07$ & $0.2 \pm 0.01$ & $0.03 \pm 0.01$ \\
\hline & Average & $12.1 \pm 0.17$ & $7.1 \pm 0.14$ & $5 \pm 0.02$ & $5.4 \pm 0.05$ & $1 \pm 0.02$ & $0.6 \pm 0.02$ \\
\hline \multirow{7}{*}{$\begin{array}{l}\text { Sedimentation } \\
\left(\mathrm{mg} \mathrm{cm}^{-2} \mathrm{~d}^{-1}\right)\end{array}$} & June & $12.1 \pm 0.13$ & $8.5 \pm 0.13$ & $7.4 \pm 0.5$ & $6.7 \pm 0.27$ & $0.8 \pm 0.01$ & $0.5 \pm 0.01$ \\
\hline & July & $11 \pm 0.1$ & $7.2 \pm 0.1$ & $6 \pm 0.03$ & $5.5 \pm 0.23$ & $0.5 \pm 0.02$ & $0.5 \pm 0.02$ \\
\hline & August & $9.3 \pm 0.1$ & $5.6 \pm 0.14$ & $4.5 \pm 0.27$ & $4.1 \pm 0.03$ & $0.4 \pm 0.01$ & $0.2 \pm 0.01$ \\
\hline & September & $6.7 \pm 0.03$ & $2.4 \pm 0.05$ & $2.2 \pm 0.08$ & $2.2 \pm 0.05$ & $0.1 \pm 0.06$ & $0.1 \pm 0.06$ \\
\hline & October & $6.2 \pm 0.45$ & $2.2 \pm 0.13$ & $1.6 \pm 0.03$ & $1.7 \pm 0.07$ & $0.1 \pm 0.01$ & $0.04 \pm 0.01$ \\
\hline & November & $5.8 \pm 0.45$ & $2.1 \pm 0.13$ & $1.5 \pm 0.03$ & $1.5 \pm 0.07$ & $0.1 \pm 0.01$ & $0.02 \pm 0.01$ \\
\hline & Average & $8.5 \pm 0.13$ & $4.7 \pm 0.07$ & $3.9 \pm 0.13$ & $3.6 \pm 0.04$ & $0.3 \pm 0.01$ & $0.2 \pm 0.01$ \\
\hline \multirow[t]{7}{*}{$\mathrm{TSS}\left(\mathrm{mg} \mathrm{L}^{-1}\right)$} & June & $27.4 \pm 0.16$ & $19.9 \pm 0.5$ & $11.9 \pm 0.05$ & $12.4 \pm 0.05$ & $2.7 \pm 0.08$ & $1.9 \pm 0.08$ \\
\hline & July & $24 \pm 0.12$ & $15.2 \pm 0.42$ & $9.5 \pm 0.4$ & $10.5 \pm 0.12$ & $2 \pm 0.16$ & $1.4 \pm 0.16$ \\
\hline & August & $18.8 \pm 0.54$ & $10.6 \pm 0.68$ & $7.3 \pm 0.17$ & $7.9 \pm 0.21$ & $1.6 \pm 0.11$ & $0.9 \pm 0.08$ \\
\hline & September & $10.5 \pm 0.52$ & $4.9 \pm 0.16$ & $3.8 \pm 0.05$ & $4.1 \pm 0.12$ & $0.7 \pm 0.13$ & $0.36 \pm 0.05$ \\
\hline & October & $8.1 \pm 0.48$ & $3 \pm 0.02$ & $3.9 \pm 0.08$ & $4 \pm 0.13$ & $0.4 \pm 0.02$ & $0.06 \pm 0.01$ \\
\hline & November & $7 \pm 0.09$ & $2.2 \pm 0.04$ & $3.8 \pm 0.1$ & $3.8 \pm 0.08$ & $0.27 \pm 0.02$ & $0.04 \pm 0.01$ \\
\hline & Average & $16 \pm 0.26$ & $9.3 \pm 0.16$ & $6.7 \pm 0.04$ & $7.1 \pm 0.07$ & $1.3 \pm 0.01$ & $0.8 \pm 0.02$ \\
\hline
\end{tabular}

Note: mean followed by standard deviation from three replicates

and 10.2 $\pm 3.87 \mathrm{ppt}$, respectively. In contrast to the SST and salinity; there were decreases in water depth $(1.3 \pm 0.05 \mathrm{~m})$, turbidity ($7.5 \pm 5.17$ NTU), sedimentation $(-4.2 \pm 2.27$ $\left.\mathrm{mg} \mathrm{cm}^{-2} \mathrm{~d}^{-1}\right)$ and TSS $\left(-9.9 \pm 6.83 \mathrm{mg} \mathrm{L}^{-1}\right)$ Journal of Wetlands Environmental Management Vol 8, No 2 (2020) 45 - 62 http://dx.doi.org/10.20527/10.20527/jwem.v8i1.216 during study period. Between August and September 2015 environmental parameters in all sites changed significantly. The SST and salinity increased in all sites by $0.75 \pm 0.002$ ${ }^{\circ} \mathrm{C}$ and $4.1 \pm 1.04 \mathrm{ppt}$, respectively. On the 
other hand, water depth, turbidity, sedimentation and TSS in all sites during August-September 2015 period decreased by $-0.5 \pm 0.01$ meters, $-2.9 \pm 2.18$ NTU, $-1.7 \pm 0.95$ $\mathrm{mg} \mathrm{cm}^{-2} \mathrm{~d}^{-1}$ and $-3.8 \pm 2.75 \mathrm{mg} \mathrm{l}^{-1}$. The largest increase in SST was observed on the Anak Kima Reef $\left(1.57 \pm 0.606{ }^{\circ} \mathrm{C}\right)$ and, the largest increase in salinity was noticed on the Ibu Reef $(14.9 \pm 5.98 \mathrm{ppt})$ (Table 1). The largest decreases in water depth, turbidity, sedimentation and TSS were discovered on the Anak Kima Reef $(-1.7 \pm 0.71 \mathrm{~m})$, the Ibu Reef (-15.5 \pm 6.19 NTU), the Anak Kima Reef $\left(-6.46 \pm 2.655 \mathrm{mg} \mathrm{cm}^{-2} \mathrm{~d}^{-1}\right)$, and the Ibu Reef $\left(-20.5 \pm 8.159 \mathrm{mg} \mathrm{L}^{-1}\right)$ (Table 1).

\section{Colony bleaching and mortality}

The total coral colonies observed from June to November 2015 were 12,954 colonies, consisted of 983 colonies on the Ibu, 2,391 colonies on the Anak Kima, 2,495 colonies on the Kima, 2,416 colonies on the Bajangan Atak, 2,355 colonies on the Batu Anjir and 2,312 on the Bajangan Reefs. No bleached coral colony was observed in the first sampling (June 3, 2015). Four weeks later (July 7, 2017), 1.4 $\pm 0.23 \%$ moderate bleached and $0.5 \pm 0.10 \%$ severe bleached from the total colony were observed for all reefs. At 8th week (August 7, 2015), it was found that $3.2 \pm 0.44 \%$ of total reefs was moderate bleached, $1.6 \pm 0.27 \%$ was severe bleached and $0.1 \pm 0.01 \%$ was dead colonies. On September 8, 2015, it was observed that $6.3 \pm 0.89 \%$ of total reefs was moderate bleached, $4.2 \pm 50.0 .71 \%$ was severe bleached and $0.2 \pm 0.02 \%$ was dead colonies. Furthermore, the proportion of bleached and dead colonies for all reefs increased dramatically to $31.3 \pm 3.18 \%$ and $3.5 \pm 0.416 \%$ in October 8, 2015 and to $45.4 \pm 3.36 \%$ and $14.7 \pm 2.29 \%$ in November 7 , 2015, respectively (Figure 2.)
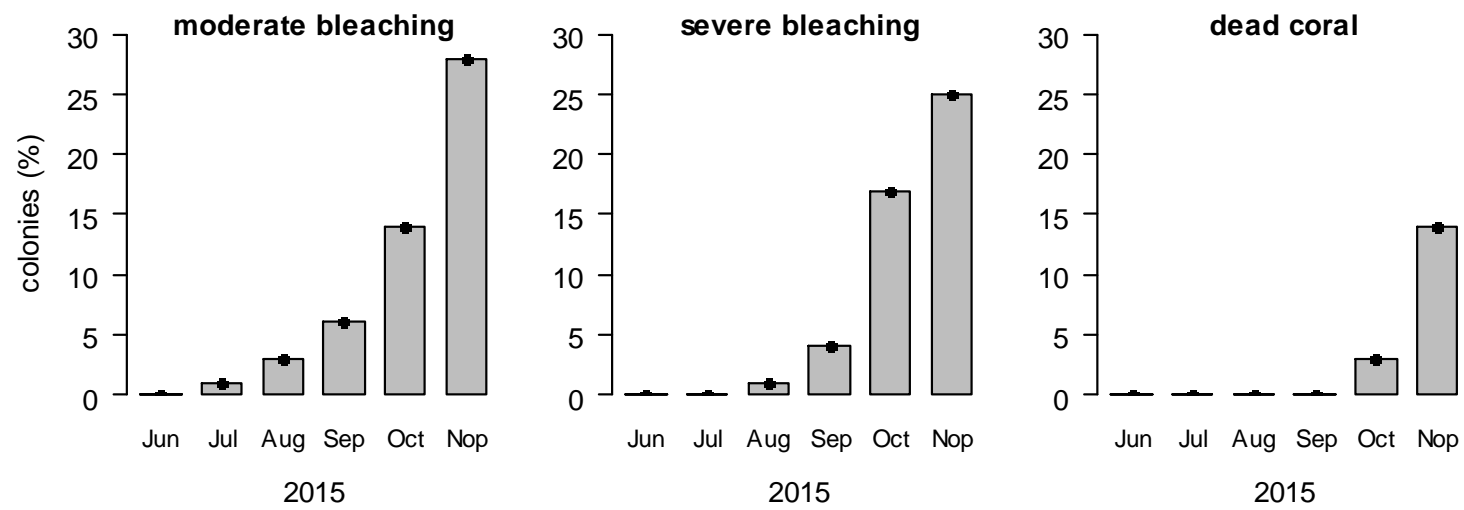

Figure 2. The Percentage of bleached and dead coral colonies at six sites from June to November 2015

The lowest proportion of colonies was bleached from the total colony of each site was observed on the Ibu Reef $(34.2 \pm 0.71 \%)$, while the highest was found on the Kima Reef $(51.7 \pm 0.25 \%)$. The dead colonies during sampling period ranged from

Journal of Wetlands Environmental Management

Vol 8, No 2 (2020) 45 - 62

http://dx.doi.org/10.20527/10.20527/jwem.v8i1.216
$3.5 \pm 0.47 \%$ on the Ibu Reef to $30.4 \pm 0.04 \%$ on the Anak Kima Reef (Figure 3). In November 2015, coral colonies survived from the thermal stress were $62.4 \%$ on the Ibu, $28.0 \%$ on the Anak Kima, $34.6 \%$ on the Kima, $38.2 \%$ on the Bajangan Atak, $42.7 \%$ 


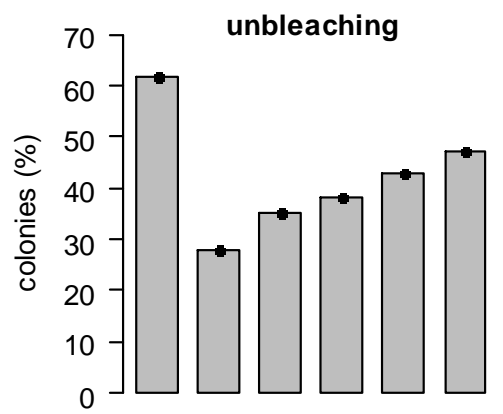

lbu AKm Kim BjA BAn Bjg 2015

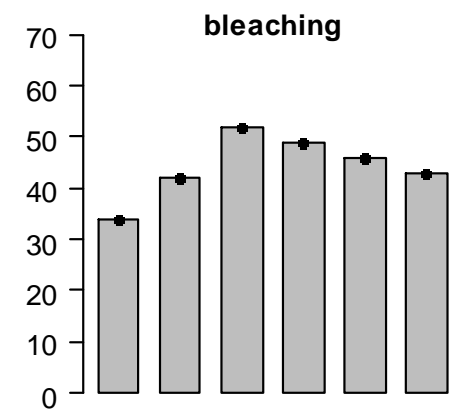

lbu AKm Kim BjA BAn Bjg

2015

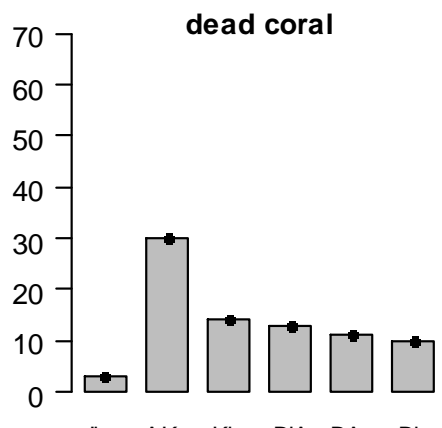

lbu AKm Kim BjA BAn Bjg 2015

Figure 3. The Percentage of bleached and dead coral colonies at six sites from June to November 2015. (Ibu: Ibu, AKm: Anak Kima, BjA: Bajangan Atak, BAn: Batu Anjir, and Bjg: Bajangan Reefs)
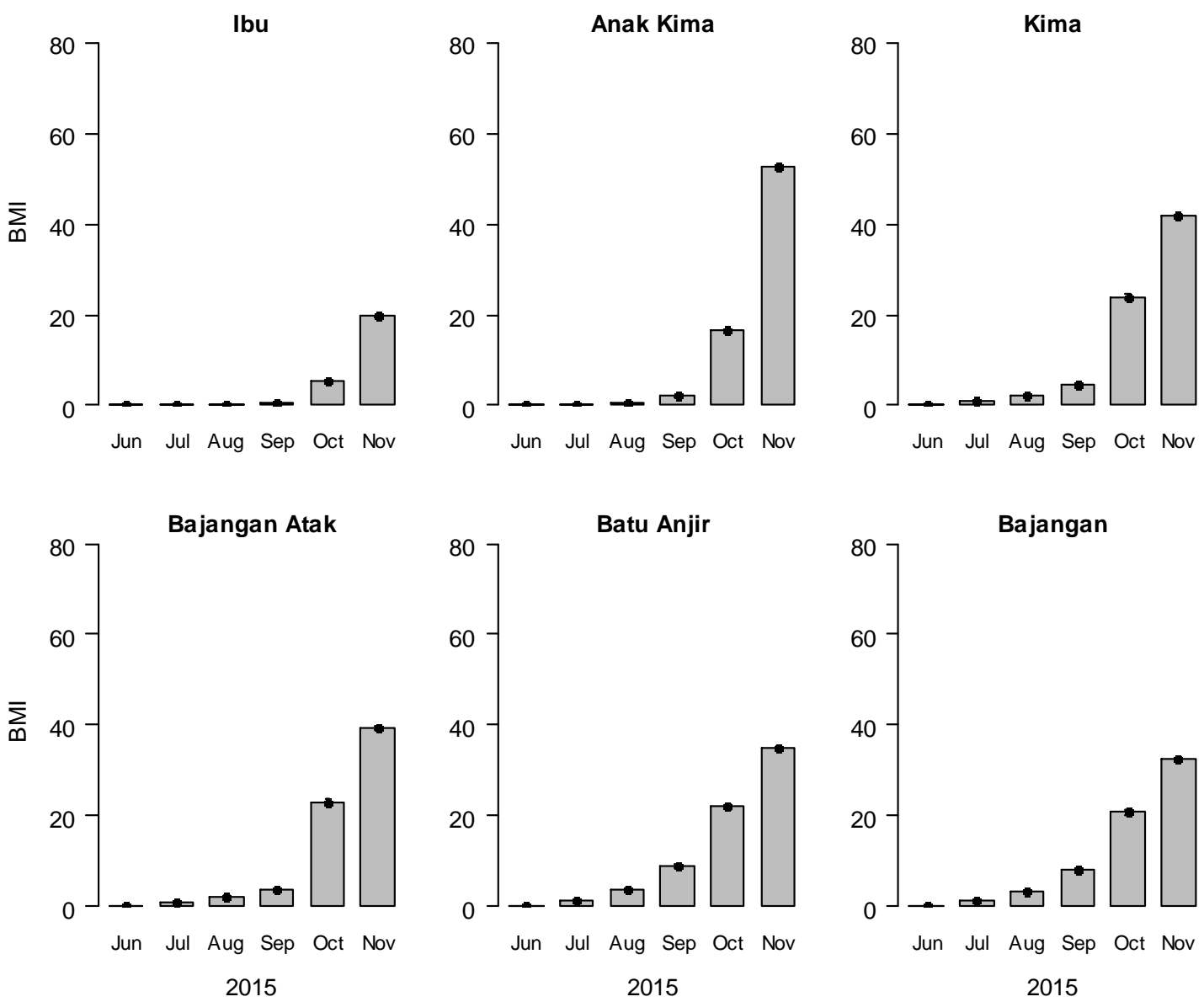

Figure 4. Bleaching Mortality Index (BMI) on six sitexs from June to November, 2015

Journal of Wetlands Environmental Management

Vol 8, No 2 (2020) $45-62$

http://dx.doi.org/10.20527/10.20527/jwem.v8i1.216 
on the Batu Anjir, and $47.3 \%$ on the Bajangan, respectively.

\section{Bleaching response pattern}

Bleaching mortality index (BMI) for all sites ranged from $0.03 \pm 0.1$ on the Ibu Reef to $53.0 \pm 0.5$ on the Anak Kima Reef during study period (Figure 4). The average of BMI in July 2015 was $0.75 \pm 0.6$ and then increased significantly to an average of 36.5 \pm 10.2 in November 2015 (Figure 4).

The BMI on the Batu Anjir and the Bajangan Reefs $(1.3 \pm 0.2)$ in July 2015 was larger than the other four sites, which ranged from $0.03 \pm 0.0$ (Ibu Reef) to $0.99 \pm 0.0$ (Bajangan Atak Reef). This pattern continued until September 2015, in which the BMI for the two sites (Batu Ajir and Bajangan Reefs) reached to $8.5 \pm 0.6$, while other four sites ranged from $0.75 \pm 0.1$ (Ibu Reef) to $4.6 \pm 0.2$ (Kima Reef). The pattern of coral bleaching and mortality changed significantly in October 2015. The BMI on Batu Anjir and Bajangan Reefs (mean 21.4 \pm 0.8 ) was smaller than the BMI on Kima and Bajangan Atak Reefs (mean 23.5 \pm 0.8 ). The pattern of coral bleaching and mortality showed subsequent changes in Nopember 2015, in which the Anak Kima Reef exhibited the largest BMI $(52.5 \pm 0.5)$ compared to other five sites (average 33.6 \pm 8.0 ). The Ibu Reef showed the lowest bleaching and mortality compared to other sites throughout the observation period.

Results of two-dimensional, non-metric multidimensional scaling (NMDS) analysis of environmental factors and the BMI for the combination of sites and time revealed that the stress value was 0.022 . The NMDS biplot graph (Figure 5) showed that there was an association between one and the other environmental factors and with BMI on different combinations of sites and times (objects).

Water depth, SST and salinity based on the NMDS1 axis were negatively correlated with turbidity, total suspended solids and sedimentation (Figure 5). Furthermore, turbidity, total suspended solids and sedimentation based on to both NMDS1 and NMDS2 axes were negatively correlated with BMI (Spearman's rank correlation = 1,000), while on the contrary positively correlated with water depth, SST and salinity (Spearman's correlation rank $=1,000$ ).

Results of the NMDS analysis also showed that environmental factors play an important role in influencing the BMI. There was a positive correlation between the BMI and the SST values. This relation was presented in the NMDS1 axis, in which bleaching, and mortality were very strong in the the Anak Kima, Kima, Bajangan Atak, Batu Anjir dan Bajangan Reefs in October and November 2015, while the relationship in the Ibu Reef remained weak.

\section{Spatial and temporal variation in bleaching responses}

All environmental factors and the BMI were significantly different for both sites and months, and the combination of sites and months; except for water depth and the SST in which the interactions between sites and months were not significantly different (Table 2). 


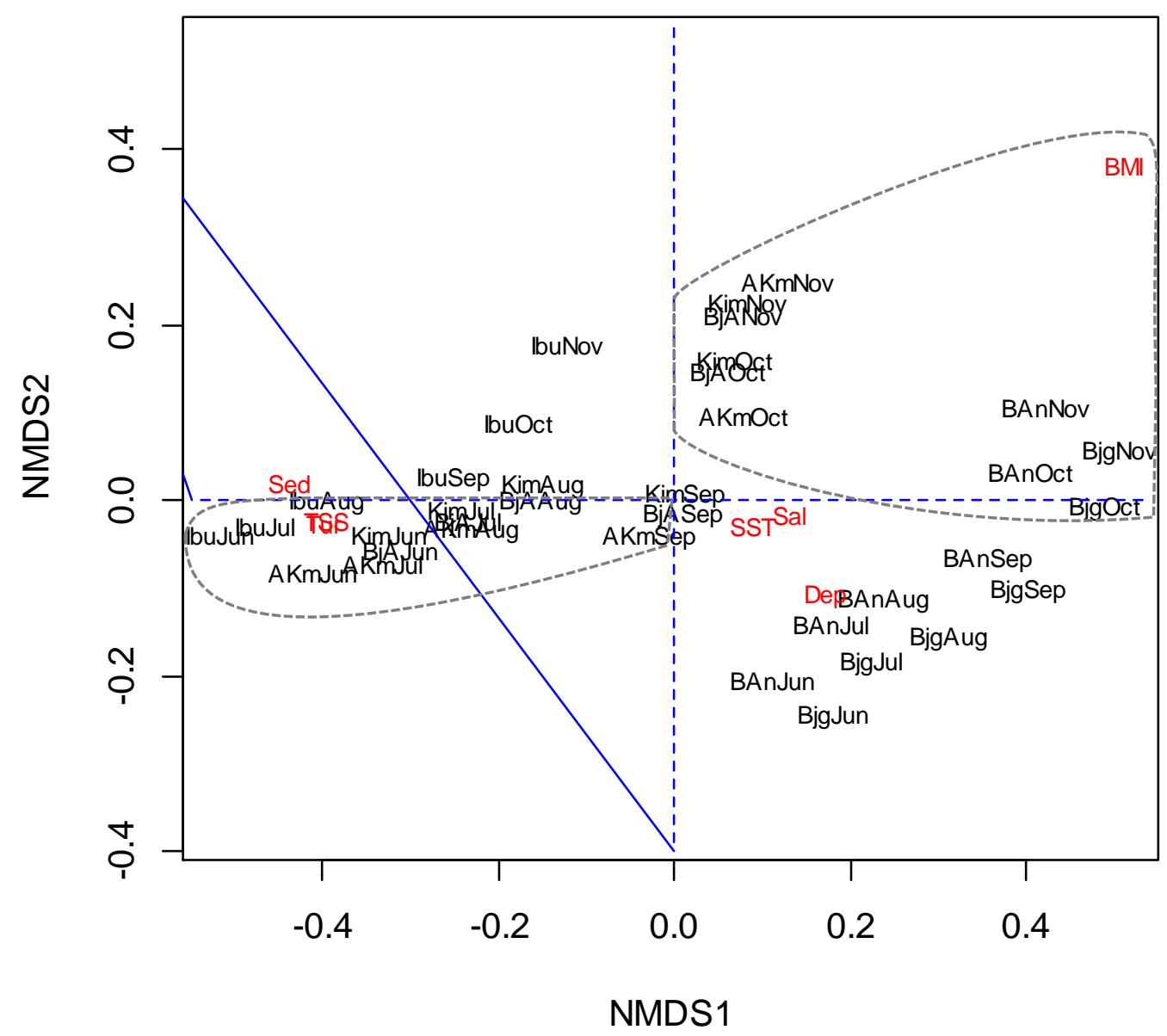

Figure 5. Two-dimensional, non-metric multidimensional scaling (NMDS). Dep: water depth, SST: sea surface temperature, Sal: salinity, Tur: turbidity, TSS: total suspended solid and Sed: sedimentation. Ibu; Ibu, Akm: Anak Kima, Kim: Kima, BjA: Bajangan Atak, Ban: Batu Anjir dan Bjg: Bajangan reefs.

Table 2. Factorial variance analysis for BMI and environmental factors

\begin{tabular}{lrcrcrr}
\hline \multirow{2}{*}{ Parameter } & \multicolumn{2}{c}{ Site } & \multicolumn{2}{c}{ Month } & \multicolumn{2}{c}{ Interaction of site and month } \\
\cline { 2 - 6 } & F-value & $\operatorname{Pr}(>\mathrm{F})$ & \multicolumn{1}{c}{ F-value } & $\operatorname{Pr}(>\mathrm{F})$ & F-value & \multicolumn{1}{l}{$\operatorname{Pr}(>\mathrm{F})$} \\
\hline BMI & 1877.30 & $<2 \mathrm{e}-16^{* * *}$ & 43375.20 & $<2 \mathrm{e}-16^{* * *}$ & 848.20 & $<2 \mathrm{e}-16^{* * *}$ \\
Water depth & 494.98 & $<2 \mathrm{e}-16^{* * *}$ & 39.31 & $<2 \mathrm{e}-16^{* * *}$ & 0.249 & 1 \\
Surface Sea Temperature & 5.22 & $3.81 \mathrm{E}-04^{* *}$ & 513.80 & $<2 \mathrm{e}-16^{* * *}$ & 0.189 & 0.999991 \\
Salinity & 674.10 & $<2 \mathrm{e}-16^{* * *}$ & 6156.20 & $<2 \mathrm{e}-16^{* * *}$ & 167.80 & $<2 \mathrm{e}-16^{* * *}$ \\
Turbidity & 9380.00 & $<2 \mathrm{e}-16^{* * *}$ & 5083.10 & $<2 \mathrm{e}-16^{* * *}$ & 526.70 & $<2 \mathrm{e}-16^{* * *}$ \\
Sedimentation & 6173.60 & $<2 \mathrm{e}-16^{* * *}$ & 2036.10 & $<2 \mathrm{e}-16^{* * *}$ & 157.70 & $<2 \mathrm{e}-16^{* * *}$ \\
Total Suspended Solid & 9449.40 & $<2 \mathrm{e}-16^{* * *}$ & 5110.70 & $<2 \mathrm{e}-16^{* * *}$ & 525.80 & $<2 \mathrm{e}-16^{* * *}$ \\
\hline
\end{tabular}


The BMI of Kima, Bajangan Atak, Batu Anjir and Bajangan Reefs increased significantly from July to November 2015, while the increase in the BMI on Ibu and Anak Kima Reefs were observed from September and to November 2015. The BMI of the Ibu and the Anak Kima Reefs, the Kima and the Bajangan Atak Reefs and the Batu Anjir and the Bajangan Reefs were not different in the period of July to September 2015 (Table 3). However, the BMI of the Ibu and the Anak Kima Reefs were significatnly different in the period of October and November 2015, while the BMI of the Kima and the Bajangan Atak Reefs, and the Batu Anjir and the Bajangan remaineds not different until the end of the study period. During the period of June to September 2015, the BMI of the Batu Anjir and the Bajangan Reefs were significantly greater than that of the Ibu and the Anak Kima Reefs and the Kima and the Bajangan Atak Reefs. On the other hand, the BMI of the Kima and the Bajangan Atak was higher than the others in October 2015, and the BMI of the Anak Kima, Kima and the Bajangan Atak Reefs were higher than that of the Batu Anjir and the Bajangan Reefs in November 2015.

Table 3. Multiple comparison test with Tukey HSD.

\begin{tabular}{|c|c|c|c|c|c|c|c|c|c|c|c|c|c|}
\hline \multirow{2}{*}{$\frac{\text { BMI:Sites }}{\text { BAn-Akm }}$} & \multirow[b]{2}{*}{$=0$} & \multirow{2}{*}{$\begin{array}{r}\text { Estimate } \\
2.9800\end{array}$} & \multirow{2}{*}{$\begin{array}{r}\text { Std. Error } \\
0.2430\end{array}$} & \multirow{2}{*}{$\frac{\mathrm{t} \text { value }}{12.263}$} & \multicolumn{2}{|c|}{$\operatorname{Pr}(>|t|)$} & \multicolumn{2}{|c|}{ BMI:Month } & \multirow{2}{*}{$\begin{array}{r}\text { Estimate } \\
-0.5567\end{array}$} & \multirow{2}{*}{$\begin{array}{r}\text { Std. Error } \\
0.2430\end{array}$} & \multirow{2}{*}{$\frac{\mathrm{t} \text { value }}{-2.291}$} & \multicolumn{2}{|c|}{$\operatorname{Pr}(>|t|)$} \\
\hline & & & & & $<1 \mathrm{e}-04$ & *** & Jul-Aug & $=0$ & & & & 0.211 & \\
\hline $\mathrm{BjA}-\mathrm{Akm}$ & $=0$ & 1.5400 & 0.2430 & 6.337 & $<1 \mathrm{e}-04$ & $* * *$ & Jun-Aug & $=0$ & -0.6000 & 0.2430 & -2.469 & 0.147 & \\
\hline Bjg-Akm & $=0$ & 2.7600 & 0.2430 & 11.358 & $<1 \mathrm{e}-04$ & $* * *$ & Nov-Aug & $=0$ & 51.8867 & 0.2430 & 213.519 & $<0.001$ & $* * *$ \\
\hline Ibu-Akm & $=0$ & -0.3633 & 0.2430 & -1.495 & 0.6680 & & Oct-Aug & $=0$ & 16.0167 & 0.2430 & 65.910 & $<0.001$ & $* * *$ \\
\hline Kim-Akm & $=0$ & 1.4967 & 0.2430 & 6.159 & $<1 \mathrm{e}-04$ & *** & Sep-Aug & $=0$ & 1.5433 & 0.2430 & 6.351 & $<0.001$ & $* * *$ \\
\hline BjA-BAn & $=0$ & -1.4400 & 0.2430 & -5.926 & $<1 \mathrm{e}-04$ & $* * *$ & Jun-Jul & $=0$ & -0.0433 & 0.2430 & -0.178 & 1 & \\
\hline Bjg-BAn & $=0$ & -0.2200 & 0.2430 & -0.905 & 0.9440 & & Nov-Jul & $=0$ & 52.4433 & 0.2430 & 215.810 & $<0.001$ & $* * *$ \\
\hline Ibu-BAn & $=0$ & -3.3433 & 0.2430 & -13.758 & $<1 \mathrm{e}-04$ & $* * *$ & Oct-Jul & $=0$ & 16.5733 & 0.2430 & 68.201 & $<0.001$ & $* * *$ \\
\hline Kim-BAn & $=0$ & -1.4833 & 0.2430 & -6.104 & $<1 \mathrm{e}-04$ & $* * *$ & Sep-Jul & $=0$ & 2.1000 & 0.2430 & 8.642 & $<0.001$ & $* * *$ \\
\hline $\mathrm{Bjg}-\mathrm{BjA}$ & $=0$ & 1.2200 & 0.2430 & 5.020 & $<1 \mathrm{e}-04$ & $* * *$ & Nov-Jun & $=0$ & 52.4867 & 0.2430 & 215.988 & $<0.001$ & $* * *$ \\
\hline Ibu-BjA & $=0$ & -1.9033 & 0.2430 & -7.832 & $<1 \mathrm{e}-04$ & $* * *$ & Oct-Jun & $=0$ & 16.6167 & 0.2430 & 68.379 & $<0.001$ & $* * *$ \\
\hline Kim-BjA & $=0$ & -0.0433 & 0.2430 & -0.178 & 1.0000 & & Sep-Jun & $=0$ & 2.1433 & 0.2430 & 8.820 & $<0.001$ & $* * *$ \\
\hline Ibu-Bjg & $=0$ & -3.1233 & 0.2430 & -12.853 & $<1 \mathrm{e}-04$ & $* * *$ & Oct-Nov & $=0$ & -35.8700 & 0.2430 & -147.609 & $<0.001$ & $* * *$ \\
\hline Kim-Bjg & $=0$ & -1.2633 & 0.2430 & -5.199 & $<1 \mathrm{e}-04$ & $* * *$ & Sep-Nov & $=0$ & -50.3433 & 0.2430 & -207.168 & $<0.001$ & $* * *$ \\
\hline Kim-Ibu & $=0$ & 1.8600 & 0.2430 & 7.654 & $<1 \mathrm{e}-04$ & $* * *$ & Sep-Oct & $=0$ & -14.4733 & 0.2430 & -59.559 & $<0.001$ & $* *$ \\
\hline Dep:Sites & & Estimate & Std. Error & $\mathrm{t}$ value & $\operatorname{Pr}(>1$ & & Dep:Mont & & Estimate & Std. Error & $\mathrm{t}$ value & $\operatorname{Pr}(>\mid t$ & \\
\hline BAn-Akm & $=0$ & 1.3000 & 0.2934 & 4.43 & $<0.001$ & $* * *$ & Jul-Aug & $=0$ & 0.1500 & 0.2934 & 0.511 & 0.99559 & \\
\hline $\mathrm{BjA}-\mathrm{Akm}$ & $=0$ & -0.7667 & 0.2934 & -2.613 & 0.1075 & & Jun-Aug & $=0$ & 0.2667 & 0.2934 & 0.909 & 0.94306 & \\
\hline Bjg-Akm & $=0$ & 3.1667 & 0.2934 & 10.792 & $<0.001$ & $* * *$ & Nov-Aug & $=0$ & -1.4000 & 0.2934 & -4.771 & $<0.001$ & $* * *$ \\
\hline Ibu-Akm & $=0$ & -1.6333 & 0.2934 & -5.566 & $<0.001$ & $* * *$ & Oct-Aug & $=0$ & -1.1000 & 0.2934 & -3.749 & 0.00466 & $* *$ \\
\hline Kim-Akm & $=0$ & -1.5333 & 0.2934 & -5.225 & $<0.001$ & **** & Sep-Aug & $=0$ & -0.6000 & 0.2934 & -2.045 & 0.32784 & \\
\hline BjA-BAn & $=0$ & -2.0667 & 0.2934 & -7.043 & $<0.001$ & $* * *$ & Jun-Jul & $=0$ & 0.1167 & 0.2934 & 0.398 & 0.99867 & \\
\hline Bjg-BAn & $=0$ & 1.8667 & 0.2934 & 6.361 & $<0.001$ & $* * *$ & Nov-Jul & $=0$ & -1.5500 & 0.2934 & -5.282 & $<0.001$ & $* * *$ \\
\hline Ibu-BAn & $=0$ & -2.9333 & 0.2934 & -9.996 & $<0.001$ & $* * *$ & Oct-Jul & $=0$ & -1.2500 & 0.2934 & -4.26 & $<0.001$ & $* * *$ \\
\hline Kim-BAn & $=0$ & -2.8333 & 0.2934 & -9.656 & $<0.001$ & & Sep-Jul & $=0$ & -0.7500 & 0.2934 & -2.556 & 0.12196 & \\
\hline Bjg-BjA & $=0$ & 3.9333 & 0.2934 & 13.404 & $<0.001$ & $* * *$ & Nov-Jun & $=0$ & -1.6667 & 0.2934 & -5.68 & $<0.001$ & $* * *$ \\
\hline Ibu-BjA & $=0$ & -0.8667 & 0.2934 & -2.953 & 0.0469 & $*$ & Oct-Jun & $=0$ & -1.3667 & 0.2934 & -4.657 & $<0.001$ & $* * *$ \\
\hline Kim-BjA & $=0$ & -0.7667 & 0.2934 & -2.613 & 0.1075 & & Sep-Jun & $=0$ & -0.8667 & 0.2934 & -2.953 & 0.04667 & $*$ \\
\hline Ibu-Bjg & $=0$ & -4.8000 & 0.2934 & -16.358 & $<0.001$ & $* * *$ & Oct-Nov & $=0$ & 0.3000 & 0.2934 & 1.022 & 0.90894 & \\
\hline Kim-Bjg & $=0$ & -4.7000 & 0.2934 & -16.017 & $<0.001$ & $* * *$ & Sep-Nov & $=0$ & 0.8000 & 0.2934 & 2.726 & 0.08248 & \\
\hline Kim-Ibu & $=0$ & 0.1000 & 0.2934 & 0.341 & 0.9994 & & Sep-Oct & $=0$ & 0.5000 & 0.2934 & 1.704 & 0.53375 & \\
\hline
\end{tabular}


Table 3. (Continued)

\begin{tabular}{|c|c|c|c|c|c|c|c|c|c|c|c|c|c|}
\hline \multirow{2}{*}{$\begin{array}{l}\text { SST:Sites } \\
\text { BAn-Akm }\end{array}$} & \multirow[b]{2}{*}{$=0$} & \multirow{2}{*}{$\begin{array}{c}\text { Estimate } \\
-2.00 \mathrm{E}-01\end{array}$} & \multirow{2}{*}{$\begin{array}{r}\text { Std. Error } \\
9.85 \mathrm{E}-02\end{array}$} & \multirow{2}{*}{$\begin{array}{r}\mathrm{t} \text { value } \\
-2.03\end{array}$} & \multicolumn{2}{|c|}{$\operatorname{Pr}(>|t|)$} & \multicolumn{2}{|l|}{ SST:Month } & \multirow{2}{*}{$\begin{array}{r}\text { Estimate } \\
-0.150\end{array}$} & \multirow{2}{*}{$\begin{array}{r}\text { Std. Error } \\
0.099\end{array}$} & \multirow{2}{*}{$\begin{array}{l}\mathrm{t} \text { value } \\
-1.522\end{array}$} & \multicolumn{2}{|l|}{$\operatorname{Pr}(>|t|)$} \\
\hline & & & & & 0.336 & & Jul-Aug & $=0$ & & & & 0.65108 & \\
\hline BjA-Akm & $=0$ & $-1.00 \mathrm{E}-01$ & $9.85 \mathrm{E}-02$ & -1.015 & 0.911 & & Jun-Aug & $=0$ & -0.350 & 0.099 & -3.552 & 0.00853 & $* *$ \\
\hline Bjg-Akm & $=0$ & $-2.33 \mathrm{E}-01$ & $9.85 \mathrm{E}-02$ & -2.368 & 0.181 & & & $=0$ & 217 & .099 & 12.349 & $<0.001$ & $* * *$ \\
\hline Ibu-Akm & $=0$ & $-3.33 \mathrm{E}-02$ & $9.85 \mathrm{E}-02$ & -0.338 & 0.999 & & ct-Aug & $=0$ & 0.883 & 0.099 & 8.966 & $<0.001$ & $* * *$ \\
\hline Kim-Akm & $=0$ & $-3.33 \mathrm{E}-02$ & $9.85 \mathrm{E}-02$ & -0.338 & 0.999 & & & $=0$ & 0.750 & 0.099 & & $<0.001$ & $* * *$ \\
\hline BjA-BAn & $=0$ & $1.00 \mathrm{E}-01$ & $9.85 \mathrm{E}-02$ & 1.015 & 0.911 & & In-Jul & $=0$ & -0.200 & 0.099 & -2.03 & 0.3359 & \\
\hline Bjg-BAn & $=0$ & $-3.33 \mathrm{E}-02$ & $9.85 \mathrm{E}-02$ & -0.338 & 0.999 & & Tov-Jul & $=0$ & 1.367 & 0.099 & 13.872 & $<0.001$ & $* * *$ \\
\hline Ibu-BAn & $=0$ & $1.67 \mathrm{E}-01$ & $9.85 \mathrm{E}-02$ & 1.692 & 0.542 & & & $=0$ & 1.033 & 0.099 & 10.488 & $<0.001$ & $* * *$ \\
\hline Kim-BAn & $=0$ & $1.67 \mathrm{E}-01$ & $9.85 \mathrm{E}-02$ & 1.692 & 0.542 & & & $=0$ & 0.900 & 0.099 & 9.135 & $<0.001$ & $* * *$ \\
\hline Bjg-BjA & $=0$ & $-1.33 \mathrm{E}-01$ & $9.85 \mathrm{E}-02$ & -1.353 & 0.754 & & ov-Jun & $=0$ & 1.567 & 0.099 & 15.902 & $<0.001$ & $* * *$ \\
\hline Ibu-BjA & $=0$ & $6.67 \mathrm{E}-02$ & $9.85 \mathrm{E}-02$ & 0.677 & 0.984 & & & $=0$ & 1.233 & 0.099 & 12.518 & $<0.001$ & $* * *$ \\
\hline Kim-BjA & $=0$ & $6.67 \mathrm{E}-02$ & $9.85 \mathrm{E}-02$ & 0.677 & 0.984 & & & $=0$ & & 0.099 & & $<0.001$ & \\
\hline Ibu-Bjg & $=0$ & $2.00 \mathrm{E}-01$ & $9.85 \mathrm{E}-02$ & 2.03 & 0.336 & & & $=0$ & -0.333 & 0.099 & -3.383 & 0.01424 & $*$ \\
\hline Kim-Bjg & $=0$ & $2.00 \mathrm{E}-01$ & $9.85 \mathrm{E}-02$ & 2.030 & 0.336 & & & $=0$ & -0.467 & 0.099 & -4.737 & $<0.001$ & \\
\hline & $=0$ & & & & 1.000 & & & $=0$ & & & & & \\
\hline Sal:Sites & & Estimate & Std. Error & $\mathrm{t}$ value & $\operatorname{Pr}(>\mid t$ & & Sal:Month & & Estimate & Std. Error & $\mathrm{t}$ value & $\operatorname{Pr}(>|t|)$ & \\
\hline BAn-Akm & $=0$ & 1.4667 & 0.1920 & 7.64 & $<0.001$ & $* * *$ & Jul-Aug & $=0$ & -4.6000 & 0.1920 & -24.0 & $<0.001$ & $* * *$ \\
\hline & $=0$ & & & 1.91 & 0.405 & & & $=0$ & & 0.1920 & & $<0.001$ & $* * *$ \\
\hline Bjg-Akm & $=0$ & & & 9.897 & $<0.001$ & $* * *$ & & $=0$ & & 0.1920 & 26.2 & $<0.001$ & $* * *$ \\
\hline Ibu-Akm & $=0$ & -1.8000 & 1920 & -9.377 & $<0.001$ & $* * *$ & & $=0$ & 4.6667 & 0.1920 & 24.3 & $<0.001$ & $* * *$ \\
\hline Kim-Akm & $=0$ & 0.0667 & 1920 & 0.347 & 0.999 & & & $=0$ & & & .1 & $<0.001$ & $* * *$ \\
\hline BjA-BAn & $=0$ & & & & $<0.001$ & $* * *$ & & $=0$ & & & & $<0.001$ & $* * *$ \\
\hline Bjg-BAn & $=0$ & 1333 & 1920 & 2.257 & 0.225 & & & $=0$ & & 0.1920 & 50.2 & $<0.001$ & $* * *$ \\
\hline BAn & $=0$ & .2667 & 1920 & -17.017 & $<0.001$ & $* * *$ & & $=0$ & & .1920 & 48.3 & $<0.001$ & $* * *$ \\
\hline a-BAn & $=0$ & & & & $<0.001$ & $* * *$ & & & & & & $<0.001$ & $* * *$ \\
\hline Bjg-BjA & $=0$ & 5333 & 1920 & 7.987 & $<0.001$ & $* * *$ & & $=0$ & 33 & 0.1920 & 71.5 & $<0.001$ & $* * *$ \\
\hline Ibu-BjA & $=0$ & .1667 & 1920 & -11.287 & $<0.001$ & $* * *$ & & $=0$ & & .1920 & 69.6 & $<0.001$ & $* * *$ \\
\hline Kim-BjA & $=0$ & & & -1.563 & 0.625 & & & $=0$ & & & 68.4 & $<0.001$ & \\
\hline Ibu-Bjg & $=0$ & -3.7000 & 1920 & -19.274 & $<0.001$ & $* * *$ & & $=0$ & & 0.1920 & -1.9 & 4.05E-01 & \\
\hline Kim-Bjg & $=0$ & -1.8333 & 1920 & -9.55 & $<0.001$ & $* * *$ & & $=0$ & & 20 & -3.1 & 0.0295 & * \\
\hline & $=0$ & & & & $<0.001$ & $* * *$ & & $=0$ & & 0.1920 & -1.2 & 0.8279 & \\
\hline Tur:Sites & & & & & $\mathrm{Pr}$ & & & & & rror & & $\operatorname{Pr}(>|t|)$ & \\
\hline BAn-Akm & $=0$ & -7.0333 & 0.1522 & -46.205 & $<0.001$ & $* * *$ & $\overline{\text { Jul- }}$ & $=0$ & 3.5833 & 0.1522 & 23.54 & $<0.001$ & $* * *$ \\
\hline BjA-Akm & $=0$ & -2.0767 & 1522 & -13.643 & $<0.001$ & $* * *$ & & $=0$ & & 0.1522 & 46.358 & $<0.001$ & $* * *$ \\
\hline jg-Akm & $=0$ & -7.4100 & .1522 & -48.679 & $<0.001$ & $* * *$ & & $=0$ & & 522 & & $<0.001$ & $* * *$ \\
\hline Ibu-Akm & $=0$ & 6.3700 & .1522 & 41.847 & $<0.001$ & $* * *$ & & $=0$ & & 0.1522 & -39.001 & $<0.001$ & $* * *$ \\
\hline Kim-Akm & $=0$ & & 1522 & -16.949 & $<0.001$ & $* * *$ & & $=0$ & & 1522 & -28.489 & $<0.001$ & $* * *$ \\
\hline BjA-BAn & $=0$ & & & 32.562 & $<0.001$ & $* * *$ & & $=0$ & & 0.1522 & & $<0.001$ & $* * *$ \\
\hline Bjg-BAn & $=0$ & -0.3767 & 1522 & -2.474 & 0.1455 & & Nov-Jul & $=0$ & -10.0067 & .1522 & -65.738 & $<0.001$ & $* * *$ \\
\hline Ibu-BAn & $=0$ & 13.4033 & 0.1522 & 88.052 & $<0.001$ & $* * *$ & Oct-Jul & $=0$ & -9.5200 & 0.1522 & -62.541 & $<0.001$ & $* * *$ \\
\hline Kim-BAn & $=0$ & & & & $<0.001$ & $* * *$ & & $=0$ & & 0.1522 & & $<0.001$ & $* * *$ \\
\hline Bjg-BjA & $=0$ & -5.3333 & 0.1522 & -35.037 & $<0.001$ & $* * *$ & Nov-Jun & $=0$ & -13.4800 & 0.1522 & -88.556 & $<0.001$ & $* * *$ \\
\hline Ibu-BjA & $=0$ & 8.4467 & 1522 & 55.49 & $<0.001$ & $* * *$ & Oct-Jun & $=0$ & -12.9933 & 0.1522 & -85.359 & $<0.001$ & $* * *$ \\
\hline Kim-BjA & $=0$ & & & & 0.0178 & $*$ & & $=0$ & & & -74.848 & $<0.001$ & $* * *$ \\
\hline Ibu-Bjg & $=0$ & 13.7800 & 0.1522 & 90.527 & $<0.001$ & $* * *$ & Oct-Nov & $=0$ & 0.4867 & 0.1522 & 3.197 & 0.0242 & $*$ \\
\hline Kim-Bjg & $=0$ & 4.8300 & 0.1522 & 31.73 & $<0.001$ & $* * *$ & Sep-Nov & $=0$ & 2.0867 & 0.1522 & 13.708 & $<0.001$ & $* * *$ \\
\hline Kim-Ibu & $=0$ & -8.9500 & 0.1522 & -58.796 & $<0.001$ & $* * *$ & Sep-Oct & $=0$ & 1.6000 & 0.1522 & 10.511 & $<0.001$ & $* * *$ \\
\hline
\end{tabular}


Table 3. (Continued)

\begin{tabular}{|c|c|c|c|c|c|c|c|c|c|c|c|c|c|}
\hline Sed:Sites & & Estimate & Std. Error & $t$ value & \multicolumn{2}{|c|}{$\operatorname{Pr}(>|t|)$} & \multicolumn{2}{|l|}{ Sed:Month } & \multirow{2}{*}{$\begin{array}{r}\text { Estimate } \\
1.5333\end{array}$} & \multirow{2}{*}{$\begin{array}{r}\text { Std. Error } \\
0.1357\end{array}$} & \multirow{2}{*}{$\begin{array}{l}\mathrm{t} \text { value } \\
11.301\end{array}$} & \multicolumn{2}{|c|}{$\operatorname{Pr}(>|t|)$} \\
\hline BAn-Akm & $=0$ & -5.2433 & 0.1357 & -38.645 & $<0.001$ & $* * *$ & Jul-Aug & $=0$ & & & & $<0.001$ & $* * *$ \\
\hline $\mathrm{BjA}-\mathrm{Akm}$ & $=0$ & -1.5333 & 0.1357 & -11.301 & $<0.001$ & $* * *$ & an-Aug & $=0$ & 2.9000 & 0.1357 & 21.374 & $<0.001$ & $* * *$ \\
\hline Bjg-Akm & $=0$ & -5.4233 & 0.1357 & -39.971 & $<0.001$ & $* * *$ & OV-Aug & $=0$ & -3.5633 & 1357 & -26.263 & $<0.001$ & $* * *$ \\
\hline Ibu-Akm & $=0$ & 3.6600 & 0.1357 & 26.975 & $<0.001$ & $* * *$ & ct-Aug & 0 & -3.4233 & 1357 & -25.231 & $<0.001$ & $* * *$ \\
\hline Kim-Akm & $=0$ & -1.1667 & 0.1357 & -8.599 & $<0.001$ & $* * *$ & Sep-Aug & $=0$ & -3.1967 & .1357 & -23.560 & $<0.001$ & $* * *$ \\
\hline BjA-BAn & $=0$ & 3.71 & 0.1357 & 27.344 & $<0.001$ & $* * *$ & Jun-Jul & $=0$ & 1.3667 & 0.1357 & 10.073 & $<0.001$ & $* * *$ \\
\hline Bjg-BAn & $=0$ & -0.1800 & 0.1357 & -1.327 & 0.7694 & & ov-Jul & $=0$ & -5.0967 & 1357 & -37.564 & $<0.001$ & $* * *$ \\
\hline Ibu-BAn & $=0$ & 8.9033 & 0.1357 & 65.620 & $<0.001$ & $* * *$ & Oct-Jul & $=0$ & -4.9567 & .1357 & -36.532 & $<0.001$ & $* * *$ \\
\hline Kim-BAn & $=0$ & $4.0^{7}$ & & & $<0.001$ & *** & & $=0$ & -4.7300 & 1357 & -34.861 & $<0.001$ & $* * *$ \\
\hline Bjg-BjA & $=0$ & -3.8900 & 0.1357 & -28.670 & $<0.001$ & $* * *$ & v-Jun & $=0$ & -6.4633 & 0.1357 & -47.636 & $<0.001$ & $* * *$ \\
\hline Ibu-BjA & $=0$ & 5.1 & 0.1357 & 38.2 & $<0.001$ & $* * *$ & & $=0$ & -6.3 & 1357 & -46.605 & $<0.001$ & $* * *$ \\
\hline Kim-BjA & $=0$ & 0.3667 & 1357 & 702 & 0.0872 & & -Jun & $=0$ & -6.0967 & 1357 & -44.934 & $<0.001$ & $* * *$ \\
\hline Ibu-Bjg & $=0$ & 9.08 & 0.1357 & 66.946 & $<0.001$ & $* * *$ & & $=0$ & 400 & 1357 & 1.032 & 0.9057 & \\
\hline Kim-Bjg & $=0$ & 4.2 & 357 & & $<0.001$ & *** & & $=0$ & 3667 & 1357 & 2.702 & 0.0871 & \\
\hline Kim-Ibu & $=0$ & -4.8267 & 0.1357 & 74 & $<0.001$ & $* * *$ & & $=0$ & 0.2267 & 0.1357 & 1.671 & 0.5554 & \\
\hline TSS:Sites & & Estimate & Std. Error & $\mathrm{t}$ value & \multicolumn{2}{|c|}{$\operatorname{Pr}(>|t|)$} & \multicolumn{2}{|l|}{ TSS:Month } & Estim & Std. Error & $\mathrm{t}$ value & \multicolumn{2}{|c|}{$\operatorname{Pr}(>|t|)$} \\
\hline BAn-Akm & $=0$ & -9.0467 & 0.1997 & -45.292 & $<0.001$ & $* * *$ & Jul-Aug & $=0$ & 4.5633 & 0.1997 & 22.846 & $<1 \mathrm{e}-04$ & $* * *$ \\
\hline $\mathrm{BjA}-\mathrm{Akm}$ & $=0$ & -2.6767 & 0.1997 & -13.401 & $<0.001$ & $* * *$ & $\mathrm{Ju}$ & $=0$ & 9.2633 & 0.1997 & 46.377 & $<1 \mathrm{e}-04$ & $* * *$ \\
\hline Bjg-Akm & $=0$ & -9.75 & 0.1997 & -48.83 & $<0.001$ & $* * *$ & $\mathrm{~N}$ & $=0$ & -8.4133 & 0.1997 & -42.121 & $<1 \mathrm{e}-04$ & $* * *$ \\
\hline Ibu-Akm & $=0$ & 2400 & 1997 & 41.254 & $<0.001$ & $* * *$ & $t-A_{u}$ & $=0$ & -7.6033 & 0.1997 & -38.066 & $<1 \mathrm{e}-04$ & $* * *$ \\
\hline Kim-Akm & $=0$ & -3.3333 & 0.1997 & -16.688 & $<0.001$ & $* * *$ & Sep-Aug & $=0$ & -5.7300 & 0.1997 & -28.687 & $<1 \mathrm{e}-04$ & $* * *$ \\
\hline BjA-BAn & $=0$ & & 0.1997 & 31.891 & $<0.001$ & $* * *$ & & $=0$ & 4.7000 & 0.1997 & 23.531 & $<1 \mathrm{e}-04$ & $* * *$ \\
\hline Bjg-BAn & $=0$ & -0.7067 & 997 & & 0.009 & $* *$ & v-Jul & $=0$ & -12.9767 & 0.1997 & -64.968 & $<1 \mathrm{e}-04$ & $* * *$ \\
\hline Ibu-BAn & $=0$ & 17.2867 & 0.1997 & 86.546 & $<0.001$ & $* * *$ & & $=0$ & -12.1667 & 0.1997 & -60.912 & $<1 \mathrm{e}-04$ & $* * *$ \\
\hline Kim-BAn & $=0$ & 5.7133 & 0.1997 & 28.604 & $<0.001$ & $* * *$ & -Jul & $=0$ & -10.2933 & 0.1997 & -51.534 & $<1 \mathrm{e}-04$ & $* * *$ \\
\hline Bjg-BjA & $=0$ & -7.0767 & 0.1997 & -35.429 & $<0.001$ & $* * *$ & Nov-Jun & $=0$ & -17.6767 & 0.1997 & -88.498 & $<1 \mathrm{e}-04$ & $* * *$ \\
\hline Ibu-BjA & $=0$ & 10.9167 & 0.1997 & 54.654 & $<0.001$ & $* * *$ & Oct-Jun & $=0$ & -16.8667 & 0.1997 & -84.443 & $<1 \mathrm{e}-04$ & $* * *$ \\
\hline Kim-BjA & $=0$ & -0.6567 & 0.1997 & -3.288 & 0.01878 & $*$ & p-Jun & $=0$ & -14.9933 & 0.1997 & -75.064 & $<1 \mathrm{e}-04$ & $* * *$ \\
\hline & $=0$ & 17.99 & & & $<0.001$ & *** & & $=0$ & 100 & 0.1997 & 4.055 & 0.00175 & $* *$ \\
\hline Kim-Bjg & $=0$ & 6.4200 & 0.1997 & 32.142 & $<0.001$ & $* * *$ & & $=0$ & 2.6833 & 0.1997 & 13.434 & $<1 \mathrm{e}-04$ & $* * *$ \\
\hline Kim-Ibu & $=0$ & -11.5733 & 0.1997 & -57.942 & $<0.001$ & $* * *$ & Sep-Oct & $=0$ & 1.8733 & 0.1997 & 9.379 & $<1 \mathrm{e}-04$ & $* * *$ \\
\hline
\end{tabular}

$\mathrm{BMI}=$ Bleaching Mortality Index, $\operatorname{dep}=$ water depth, $\mathrm{SST}=$ sea surface temperature, sal $=$ salinity, tur= turbidity, sed: sedimentation, TSS $=$ total suspended solid. Significant codes: 0

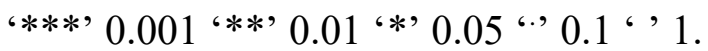

\section{DISCUSSION}

Terrestrial runoff flowing into the coastal waters of the Angsana Sub-district at the beginning of study was high, even in June 2015 there was a large flood in which the flood plumes reached partially the Kima and Bajangan Atak Reefs. Terrestrial runoff is not only supplied sediments (Humanes et al. 2017), it also flows freshwater into nearshore waters, and eventually increased turbidity (Prouty et al., 2014) and decreases salinity (Priyaet al., 2016). High sediment and turbidity potentially cause sublethal effects on corals (Bak, 1978; Rogers, 1983; Cooper et al., 2008) as well as low salinity (Kerswell and Jones, 2003; Lirman et al., 2003).

Significant increases in SST and salinity in the six sites during study period are related to the El Niño event Indonesia since 2015 (Ampou, 2017) and in South Kalimantan from June 2015. The El Niño event caused rainfall in the study area dropped to $14.5 \mathrm{~mm}$ in August and no rainy in September 2015 (Tanah Bumbu Regency Central Bureau of Statistics, 2016), so that 
the flood plume of Angsana, Bunati and Sebamban Rivers towards the sea reduced from $\pm 2.8 \mathrm{NM}$ (June 2015) to $\pm 0.9 \mathrm{NM}$ (July 2015 ) and \pm 0.24 NM (November 2015) (Asmawi, unpublished data). Furthermore, turbidity, the TSS and sedimentation dropped significantly. However, turbidity of the Ibu (until November 15), the Anak Kima (until September 2015), and the Kima and the Bajangan Atak Reefs (until October 2015) were greater than 3 NTU, which in the long period may cause corals to experience sublethal stress (Cooper et al., 2008).

The results of study showed that mass bleaching in 2015 was the major disturbance for the coral reefs in the coastal Tanah Bumbu Regency and in the southeast of Kalimantan; as a result of thermal stress (Cantin and Lough, 2014; Hughes et al., 2017; Lough et al., 2018) which were driven by the 2015-2016 El Niño (Hughes et al., 2018). No coral colonies were bleached to the six sites in June 2015. Four weeks later in which there was increases in the SST, 2\% of all coral colonies observed in the six sites were bleached and $26 \%$ were severe bleached. In August 2015, 4.3\% of bleached coral colonies in the previous month were dead. In the following months, bleached coral colonies continued to increase to reach $49.1 \%$ of the total colonies. Moreover, the proportion of dead colonies continued to increase to reach $92 \%$ of coral colonies whitened in the previous month or $29.7 \%$ of the total colonies. Generally bleaching of coral colonies observed occurred two to four weeks after the temperature increased and died within four to six weeks later. These were in line with the explanation of Baird \& Marshall (2002) and Baird et al. (2017).

The interaction between the combination of increasing temperature and irradiation Journal of Wetlands Environmental Management Vol 8, No 2 (2020) 45 - 62 http://dx.doi.org/10.20527/10.20527/jwem.v8i1.216 with environmental factors (specifically turbidity, sedimentation and TSS) makes the rate and severity of coral bleaching were different between sites. The difference results in four different bleaching patterns, where the severity of coral bleaching in (1) deep and clear waters (the Batu Anjir and the Bajangan) was very high at the beginning of the event, the bleaching rate was very fast until September 2015, then slowed to the end of the study; (2) low turbidity waters (the Kima and the Bajangan Atak) were relatively high at the beginning of the event, the bleaching rate was slow until September 2015 , then increased rapidly until the end of the study; (3) medium turbidity waters (the Anak Kima) were very low at the beginning of the event, the bleaching rate was very slow until September 2015, then increased very rapidly until the end of the study; (4) high turbidity waters (the Ibu) were very low at the beginning of the event, the bleaching rate was very slow until September 2015, then increased quickly until the end of the study. Possible explanations for coral bleaching events on reefs along the coast of the Tanah Bumbu Regency during the 2015 El Niño event are as follow. First, coral bleaching and mortality on the Batu Anjir and the Bajangan Reefs occur earlier than other four reefs, because the Batu Ajir and the Bajangan Reefs both are in clear waters, so light irradiation reached the seabed (Spencer et al., 2000) and together with high temperatures gives strong pressure on the coral since June 2015. As a result, the BMI on both sites in July to September 2015 was greater than the other four sites. At the same time, turbidity on the Ibu, Anak Kima, Kima and Bajangan Atak Reefs were are still high, in which high turbidity could function as a shade for coral from the sunlight (Fabricius, 
2005; Anthony et al., 2007), and inhibit the interaction between turbidity and thermal stress and high light intensity that could endanger corals (Storlazzi et al., 2015). Cacciapaglia and Van Woesik (2016) showed that turbidity could reduce the level of coral bleaching in the world, including the eastern part of the Sumatra and the southwest coast of the Kalimantan (Indonesia) (Cacciapaglia and Van Woesik, 2016) and this protection did not occur in deeper waters (Thompson and Dolman, 2010).

Second, a large decrease in turbidity since September 2015 (Table 1) resulted in increasing light irradiation reached the Kima and the Bajangan Atak Reefs, so that in October and November 2015 the BMI in these two sites exceeded the BMI on the Batu Anjir and the Bajangan Reefs. In addition, both coral reefs are shallow corals, in which mortality from bleaching could spread on shallow coral (Ampou, 2017). At the same time, the Ibu and Anak Kima Reefs experienced increases in thermal stress, but high turbidity still had a shade effect on both reefs that eventually not cause a surge in the BMI.

Third, long periods of high turbidity in the Anak Kima Reefs could decrease coral health (e.g. McClanahan, et al. 2004, Leggat, et al, 2011), due to barriers for symbiotic organism photosynthesis (Marcelino, et al. 2013) and additional energy expenditure to remove coral-smothered sediments (Marshall and Baird, 2000). Once turbidity decreased significantly to $2.12 \pm 0.02$ NTU (October 2015) and 1.64 \pm 0.05 NTU (November 2015), the colonies under sublethal conditions immediately received thermal stress accompanied by exposure to high irradiation. The combination of high radiation and high temperatures (e.g. Jokiel Journal of Wetlands Environmental Management Vol 8, No 2 (2020) 45 - 62 http://dx.doi.org/10.20527/10.20527/jwem.v8i1.216 and Coles, 1990; Lesser et al., 1990; Brown et al., 1994) which cause significant increases in oxidative stress when high irradiance exposure accompanied by thermal ill-treatment (Browne, 2012). As a result, the BMI increased to $52.5 \pm 0.5$ or $125.2 \%$ above the BMI of other sites. Fourth, even though there were no floods, in November 2015, turbidity on the Ibu Reef was still $5.27 \pm 0.45$ NTU, because this reef was only 0.21 NM from the coastline; therefore, it was still reached by turbid water from the Angsana River combined with resuspension sediment from shrimp trawling activities. Fishing activities with "lampara dasar" (mini trawl) ${ }^{2}$ around the Ibu Reef occurred almost throughout the year. One effect of ship traffic and trawling is basic sediment resuspension (Kaiser et al., 2002; Pusceddu et al., 2005). Furthermore Schoellhamer (1996) explains that sediment deposits originating from sediment resuspension by trawling are more easily suspended by tidal currents than undisturbed basic sediments. Continuous trawling has the potential to make terrestrial sediments in the form of suspension for a long time (Bainbridge et al., 2012; Brodie et al., 2010; Storlazzi et al., 2015) and forms a nepheloid layer that flows towards the reef (Wolanski and Spagnol, 2000), so that the turbidity is prolonged on the Ibu reef, and provides a vigorous shade effect. Whereas in the Kima and the Bajangan Atak Reefs, turbidity (average $2.89 \pm 0.07 \mathrm{NTU})$ was still higher than the Anak Kima Reef, because of the sediment resuspension due to large waves and currents. In addition, sediment resuspension

\footnotetext{
2 Illegal fishing according Regulation of the Minister of Marine and Fisheries of the Republic of Indonesia Number 2/Permen-KP/2015. January 9, 2015
} 
in the Bajangan Atak Reef is also caused by propeller wash and backflow from tugboats ${ }^{3}$ (Liao et al., 2015; van Rijn, 2018) especially during maneuver for repositioning vessels (Clarke et al., 2015).

\section{CONCLUSION}

It could be concluded that the coral bleaching responses to the combination of increasing temperature and solar irradiation due to 2015 El Niño event differed according to the level of turbidity and the depth of water in Southeast Coast of the Kalimantan. Bleaching and mortality of the reefs in deep and clear water occurred earlier than those in turbid and shallow water. Increasing turbidity resulted in decreases in the rate and the severity of coral bleaching and the mortality, but significant decreases in the turbidity caused dramatic increases in the severity of coral bleaching and the mortality. The combination of terrestrial sediments and sediment resuspension by fishing activities caused high turbidity in the Ibu Reef. This reef is continuously protected from thermal stress and high solar irradiation, so the level of bleaching and the mortality in this reef remains the lowest during the study.

\section{ACKNOWLEDGEMENTS}

This research was partly supported by the Project of Development and Upgrading of Seven Universities in Improving the Quality and Relevance of Higher Education in Indonesia, Lambung Mangkurat University and PT Tunas Inti Abadi, Sebamban Baru,

\footnotetext{
${ }^{3}$ On the coast of Angsana Sub-district there are four coal ports, so that every day dozens of tug-boats and barges pass around the Anak Kima, Batu Anjir and Bajangan reefs.

Journal of Wetlands Environmental Management

Vol 8, No 2 (2020) 45 - 62

http://dx.doi.org/10.20527/10.20527/jwem.v8i1.216
}

Loban River, Tanah Bumbu Regency, South Kalimantan

\section{REFERENCES}

Allen, G.R. and R. Steene (2003). IndoPacific Coral Reef Field Guide. Tropical Reef Research.

Ampou, E. E., Johan, O., Menkes, C. E., Niño, F., Birol, F., Ouillon, S., \& Andréfouët, S. (2017). Coral mortality induced by the 2015-2016 El-Niño in Indonesia: the effect of rapid sea level fall. Biogeosciences, 14(4), 817-826.

Athoillah, I., Sibarani, R. M., \& Doloksaribu, D. E. (2017). Analisis Spasial El Niño Kuat Tahun 2015 dan La Nina Lemah Tahun 2016 (Pengaruhnya Terhadap Kelembapan, Angin dan Curah Hujan di Indonesia). Jurnal Sains \& Teknologi Modifikasi Cuaca, 18(1), 33-41.

Baird, A. H., \& Marshall, P. A. (2002). Mortality, growth and reproduction in scleractinian corals following bleaching on the Great Barrier Reef.. Marine Ecology Progress Series, 237, 133-141.

Baird, A. H., Bhagooli, R., Ralph, P. J., \& Takahashi, S. (2009). Coral bleaching: the role of the host. Trends in Ecology \& Evolution, 24(1), 16-20.

Baird, A. H., Keith, S. A., Woolsey, E., Yoshida, R., \& Naruse, T. (2017). Rapid coral mortality following doldrums-like conditions on Iriomote, Japan. F1000Research, 6, 1728.

Baker, A. C., Glynn, P. W., \& Riegl, B. (2008). Climate change and coral reef bleaching: An ecological assessment of long-term impacts, recovery trends and future outlook. Estuarine, coastal and shelf science, 80(4), 435-471. 
Bhagooli, R., \& Hidaka, M. (2003). Comparison of stress susceptibility of in hospite and isolated zooxanthellae among five coral species. Journal of Experimental Marine Biology and Ecology, 291(2), 181-197.

Browne, N. K. (2012). Spatial and temporal variations in coral growth on an inshore turbid reef subjected to multiple disturbances. Marine environmental research, 77, 71-83.

Cantin, N. E., Negri, A. P., \& Willis, B. L. (2007). Photoinhibition from chronic herbicide exposure reduces reproductive output of reef-building corals. Marine Ecology Progress Series, 344, 81-93.

Cooper, T.F., P.V. Ridd, K.E. Ulstrup, C. Humphrey, M. Slivkoff. K.E. Fabricius. 2008. Temporal dynamics in coral bioindicators for water quality on coastal coral reefs of the Great Barrier Reef. Mar Freshw Res 59(8): 703-716.

Cooper, T.F., P.V. Ridd, K.E. Ulstrup, C. Humphrey, M. Slivkoff. K.E. Fabricius. 2008. Temporal dynamics in coral bioindicators for water quality on coastal coral reefs of the Great Barrier Reef. Mar Freshw Res 59(8): 703-716.

Cunning, R., \& Baker, A. C. (2013). Excess algal symbionts increase the susceptibility of reef corals to bleaching. Nature Climate Change, 3(3), 259.

De'ath, G., and Fabricius, K. E. (2008). Water quality of the Great Barrier Reef: distributions, effects on reef biota and trigger values for the protection of ecosystem health. Research Publication No. 89. Great Barrier Marine Park Authority, Townsville, Qld.

Devlin, M., \& Schaffelke, B. (2009). Spatial extent of riverine flood plumes and exposure of marine ecosystems in the

Journal of Wetlands Environmental Management

Vol 8, No 2 (2020) 45 - 62

http://dx.doi.org/10.20527/10.20527/jwem.v8i1.216
Tully coastal region, Great Barrier Reef. Marine and Freshwater Research, 60(11), 1109-1122.

Done, T. T., Turak, E. E., Wakeford, M. M., Kininmonth, S. S., Wooldridge, S. S., Berkelmans, R. R., ... \& Mahoney, M. M. (2003). Testing bleaching resistance hypotheses for the 2002 Great Barrier Reef bleaching event.

Donner, S. D., Skirving, W. J., Little, C. M., Oppenheimer, M., \& Hoegh-Guldberg, O. V. E. (2005). Global assessment of coral bleaching and required rates of adaptation under climate change. Global Change Biology, 11(12), 2251-2265.

Eakin, C. M., Morgan, J. A., Heron, S. F., Smith, T. B., Liu, G., Alvarez-Filip, L., ... \& Brandt, M. (2010). Caribbean corals in crisis: record thermal stress, bleaching, and mortality in 2005. PloS one, 5(11), e13969.

English, S., C. Wilkinson \& V. Baker 1997. Survey Manual for Tropical Marine Resources. Australian Institute of Marine Science, Townsville, Australia Ennis, R. S., Brandt, M. E., Grimes, K. R. W., \& Smith, T. B. (2016). Coral reef health response to chronic and acute changes in water quality in St. Thomas, United States Virgin Islands. Marine pollution bulletin, 111(1), 418-427.

Fabricius, K. E. (2005). Effects of terrestrial runoff on the ecology of corals and coral reefs: review and synthesis. Marine pollution bulletin, 50(2), 125-146.

Gilmour, J.P., Cooper, T.F., Fabricius, K.E., Smith, L.D., 2006. Early warning indicators of change in the condition of corals and coral communities in response to key anthropogenic stressors in the Pilbara, Western Australia (2006). 
Australian Institute of Marine Science, Technical report, 94pp.

Guest, J. R., Baird, A. H., Maynard, J. A., Muttaqin, E., Edwards, A. J., Campbell, S. J., ... \& Chou, L. M. (2012). Contrasting patterns of coral bleaching susceptibility in 2010 suggest an adaptive response to thermal stress. PloS one, 7(3), e33353.

Guest, J.R., Baird, A.H., Maynard, J.A., Muttaqin, E., Edwards, A.J., Campbell, S.J., Yewdall, K., Affendi, Y.A., Chou, L.M., 2012. Contrasting patterns of coral bleaching susceptibility in 2010 suggest an adaptive response to thermal stress. PloS one 7, e33353.

Hoegh-Guldberg, O., Bruno, J.F., 2010. The impact of climate change on the world's marine ecosystems. Science 328, 15231528.

Hoegh-Guldberg, O., Fine, M., 2004. Low temperatures cause coral bleaching. Coral Reefs 23, 444-444.

Hughes, T. P., Kerry, J. T., Álvarez-Noriega, M., Álvarez-Romero, J. G., Anderson, K. D., Baird, A. H., ... \& Bridge, T. C. (2017). Global warming and recurrent mass bleaching of corals. Nature, 543(7645), 373.

Iskandar, I., Utari, P. A., Lestari, D. O., Sari, Q. W., Setiabudidaya, D., Khakim, M. Y. N., ... \& Dahlan, Z. (2017, July). Evolution of 2015/2016 El Niño and its impact on Indonesia. In AIP Conference Proceedings (Vol. 1857, No. 1, p. 080001). AIP Publishing.

Jones, R. J. (2008). Coral bleaching, bleaching-induced mortality, and the adaptive significance of the bleaching response. Marine Biology, 154(1), 6580.
Jones, R.J., 2008. Coral bleaching, bleaching-induced mortality, and the adaptive significance of the bleaching response. Marine Biology 154, 65-80.

Kelley, R. (2009). Indo Pacific Coral Finder. Www.byoguides.com.

Kerswell, A.P., Jones, R.J., 2003. Effects of hypo-osmosis on the coral Stylophora pistillata: nature and cause of lowsalinity bleaching1. Marine Ecology Progress Series 253, 145-154.

Krediet, C. J., Ritchie, K. B., Paul, V. J., \& Teplitski, M. (2013). Coral-associated micro-organisms and their roles in promoting coral health and thwarting diseases. Proceedings of the Royal Society of London B: Biological Sciences, 280(1755), 20122328.

Kushmaro A, Rosenberg E, Fine M, Loya Y (1997) Bleaching of the coral Oculina patagonica by Vibrio AK-1. Mar Ecol Prog Ser 147:159-165

Leggat, W., Seneca, F., Wasmund, K., Ukani, L., Yellowlees, D., \& Ainsworth, T. D. (2011). Differential responses of the coral host and their algal symbiont to thermal stress. PloS one, 6(10), e26687.

Marcelino, L. A., Westneat, M. W., Stoyneva, V., Henss, J., Rogers, J. D., Radosevich, A., ... \& Fung, J. (2013). Modulation of light-enhancement to symbiotic algae by light-scattering in corals and evolutionary trends in bleaching..PLoS One, 8(4), e61492.

Marshall, P. A., \& Baird, A. H. (2000). Bleaching of corals on the Great Barrier Reef: differential susceptibilities among taxa. Coral reefs, 19(2), 155-163.

McClanahan, T. R., Baird, A. H., Marshall, P. A., \& Toscano, M. A. (2004). Comparing bleaching and mortality responses of hard corals between 
southern Kenya and the Great Barrier Reef, Australia. Marine Pollution Bulletin, 48(3-4), 327-335.

Negri, A. P., \& Hoogenboom, M. O. (2011). Water contamination reduces the tolerance of coral larvae to thermal stress. PLoS One, 6(5), e19703.

Negri, A., Vollhardt, C., Humphrey, C., Heyward, A., Jones, R., Eaglesham, G., $\&$ Fabricius, K. (2005). Effects of the herbicide diuron on the early life history stages of coral.Marine Pollution Bulletin, 51(1-4), 370-383.

Obura, D. O. (2001). Can differential bleaching and mortality among coral species offer useful indicators for assessment and management of reefs under stress?. Bulletin of Marine Science, 69(2), 421-442.

Obura, D.O., 2005. Resilience and climate change: lessons from coral reefs and bleaching in the Western Indian Ocean. Estuarine, Coastal and Shelf Science, 63, 353-372.

Pollock, F. J., Lamb, J. B., Field, S. N., Heron, S. F., Schaffelke, B., Shedrawi, G., ... \& Willis, B. L. (2014). Sediment and turbidity associated with offshore dredging increase coral disease prevalence on nearby reefs. PLOS one, 9(7), e102498.

R Core Team (2015). R: A language and environment for statistical computing. R Foundation for Statistical Computing, Vienna, Austria. URL http://www.Rproject.org/.

Restrepo, J. D., Zapata, P., Díaz, J. M., Garzón-Ferreira, J., \& García, C. B. (2006). Fluvial fluxes into the Caribbean Sea and their impact on coastal ecosystems: The Magdalena River,
Colombia. Global and Planetary Change, 50(1-2), 33-49.

Sparrow, L., Momigliano, P., Russ, G.R., Heimann, K., 2017. Effects of temperature, salinity and composition of the dinoflagellate assemblage on the growth of Gambierdiscus carpenteri isolated from the Great Barrier Reef. Harmful algae 65, 52-60.

van Woesik, R., Sakai, K., Ganase, A., \& Loya, Y. (2011). Revisiting the winners and the losers a decade after coral bleaching. Marine Ecology Progress Series, 434, 67-76.

Veron, J. E. (2000). Corals of the World, vol. 1-3. Australian Institute of Marine Science, Townsville, 295.

Wagner, D. E., Kramer, P., \& Van Woesik, R. (2010). Species composition, habitat, and water quality influence coral bleaching in southern Florida. Marine Ecology Progress Series, 408, 65-78.

West, J. M., \& Salm, R. V. (2003).

Resistance and resilience to coral bleaching: implications for coral reef conservation and management. Conservation Biology, 17(4), 956-967.

WoRMS Editorial Board (2015). World Register of Marine Species. Available from http://www.marinespecies.org at VLIZ. 